\title{
名古屋地方における年間野外昼光照度の数式表示 FORMULATION OF OUTDOOR DAYLIGHT ILLUMINANCE IN NAGOYA DISTRICT BASED ON THE DATA COLLECTED BY THE MEASUREMENT
}

\author{
西 安男*, 岡田恭明**, 大竹克佳***, 系山康道***, 榊 原 佳 伸*** \\ Yasuo NISHI, Yasuaki OKADA, Katsuyoshi OHTAKE, \\ Yasumichi ITOYAMA and Yoshinobu SAKAKIBARA
}

\begin{abstract}
This paper describes a study on formulating outdoor daylight illuminance (global illuminance from fine clear or fair sky, illuminance from unobstructed fine clear or fair sky, cloudy or overcast sky, and rainy sky respectively) in Nagoya district based on the data collected from the continuous measurement over about three years and six months. There are many factors that affect outdoor daylight illuminance. In this paper, weather and solar altitude are taken as two dominant factors that affect outdoor daylight illuminance. After all, this paper presents a series of equations that can evaluate daylight illuminance by taking the above-mentioned two factors into consideration.
\end{abstract}

Keywords : Formulation of outdoor daylight illuminance, Weather, Solar altitude, 野外昼光照度の数式表示、天気、太陽高度

\section{1. 緒 言}

室内採光照明におけるこれまでの研究には、小木曾による多面的な

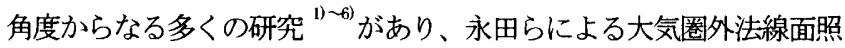
度や大気透過率・太陽高度から昼光照度を求める研究 ${ }^{7 \sim 8)}$ もある。ま た近年では、天空輝度を中心とした井川・中村 ${ }^{9) \sim 10)}$ らの研究もある。 その他にも多くの人による研究がある。筆者らも昼光光源の重要性に 着目して、幾多の研究を行い、その成果を発表してきた ${ }^{11)}$ １5)。

昼光の研究は今までにもいろいろ行われてきたし、今後も必要であ る。

筆者らは、この度、名古屋地方における野外昼光照度の実態を明ら かにしたので、それを報告する。本報告は、照度の值のみならずその 出現頻度にも言及していることで、従来の研究において幾分欠けてい た面を補う意味があると思われる。

\section{2. 野外昼光照度の実測}

本研究に执いては、晴天時のグローバル照度と、晴天時・曇天時・ 雨天時の全天空照度の実態を明らかにすることを目的とした。

* 前 名城大学理工学部建築学科 教授·工博

** 名城大学理工学部建築学科 講師 · 工博

*** 名城大学大学院理工学研究科 大学院生
本研究では、この目的を達成するために、昼光照度の実測を下記の如 く行った。

測定の期間 ; 測定期間は 1999 年 6 月 3 日〜2002 年 12 月 31 日まで の約 3.5 年間である。日没後も稼動させ、次の日の日の出まで待機さ せた所謂、連続測定である。

測定の場所; 高台に建つ名城大学 4 号館 4 階屋上で測定を行った。位 置は図 1 に示す。

測定器具; グローバル照度計 (EKO-ML-010S)、全天空照度計 (EKO-ML-010S)、直達日射計(EKO-MS-801)、感雨計(TRW-010)を用いて 観測している。

測定方法;測定したデータはコンピュータに 1 分每に採り込み、10 分毎に平均した値に処理し、日の出時から日没時までを連続収録して いる。今回のデー夕は 1999〜2002 年において、晴天 : 36555 個、曇天 : 32969 個、雨天 : 5051 個であった。全天空照度計は図 1 に示すように 直射日光を遮るための遮蔽りングを取り付けた装置を用いて測定して いる。遮蔽リングのために天空が過剩に遮蔽されてしまうことに対す る補正は行った。

Ex-Prof., Dept. of Architecture, Faculty of Science and Technology, Meijo Univ. Dr. Eng.

Lecturer, Dept. of Architecture, Faculty of Science and Technology, Meijo Univ. Dr. Eng.

Graduate Student, Graduate School of Science and Technology, Meijo Univ. 


\section{3. 得られた測定データの分析・検討}

野外昼光照度の変動要因のうち主要なものは、天気・季節・太陽高 度の 3 つであると思われる。

本研究では、当初、季節を春季、夏季、秋季、冬季の 4 季に分けて、 各季の特徵を調べたが、春季と秋季の差異は殆ど認められなかったの で、季節を春秋季・夏季・冬季に分けて、各季節の晴天時・曇天時・ 雨天時における野外昼光照度が太陽高度の変化に伴って、どのように 変化するかを検討することにした。また、季節による特徵を調べるた めに、通年の晴天時・量天時・雨天時における野外昼光照度が太陽高 度の変化に伴ってどのように変化するかも検討した。
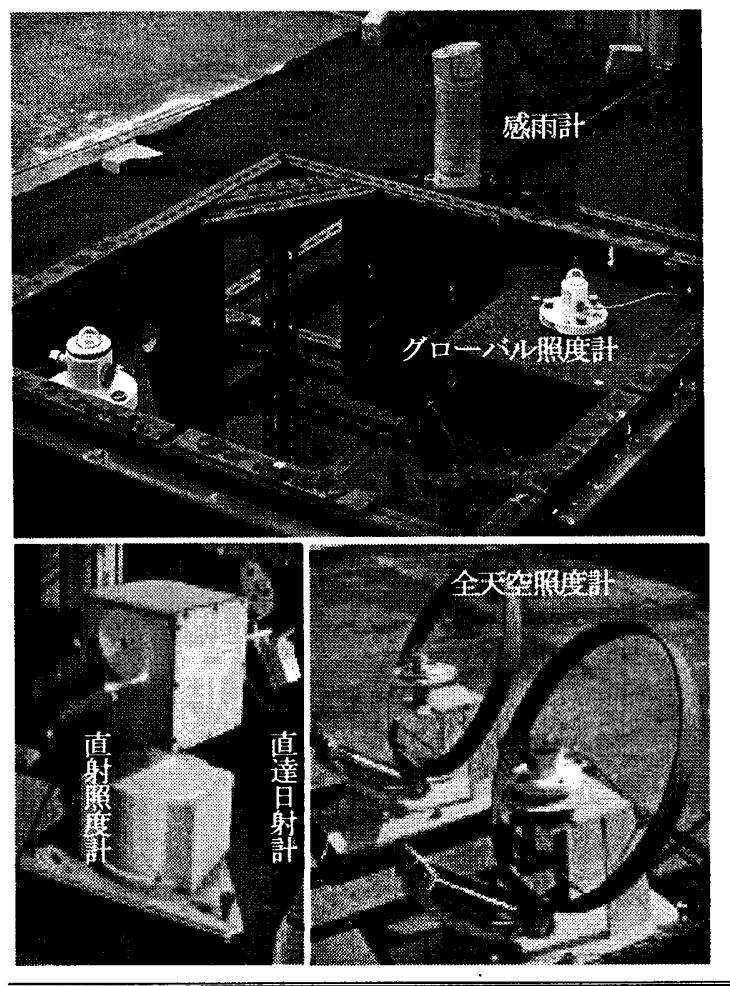

\begin{tabular}{c|c}
\hline \hline 北 緯 & $35^{\circ} 07^{\prime} 53^{\prime \prime}$ \\
\hline 東 経 & $136^{\circ} 58^{\prime} 49^{\prime \prime}$ \\
\hline 海 抜 & $58 \mathrm{~m}$ \\
\hline
\end{tabular}

図 1 測定機器と測定位置

\section{1 各季節の分類}

季節の分類は春秋季・夏季・冬季の 3 分類とした。年間を通して 4 季の一定の日数期間を約 90 日（春秋季はまとめて約 180 日）に定めて分 割し、それに対応寸る日赤緯 $(\delta)$ は表 1 のようにした。

表 1 各季節の期間と日赤緯の設定

\begin{tabular}{c|c|c}
\hline 季節 & 期間 & 日 赤 緯 $[\delta]$ \\
\hline \hline 春秋季 & $(2 / 8 \sim 5 / 8)(8 / 11 \sim 11 / 5)$ & $-15^{\circ} \sim 0^{\circ} \sim 15^{\circ}$ \\
\hline 夏季 & $(5 / 9 \sim 8 / 10)$ & $15^{\circ} \sim 23^{\circ} 27^{\prime} \sim 15^{\circ}$ \\
\hline 冬季 & $(1 / 1 \sim 2 / 7)(11 / 6 \sim 12 / 31)$ & $-15^{\circ} \sim-23^{\circ} 27^{\prime} \sim-15^{\circ}$ \\
\hline
\end{tabular}

\section{2 測定データの各天気への振り分け}

法線面直達日射の強さにより、晴天と曇天を判別することにした。
判別方法については、直達日射の強さが $120 \mathrm{~W} / \mathrm{m}^{2}$ 以上を晴天とした。 この閾值はWMO（世界気象機構）によって提唱されている值であり、 気象庁もこれを採用している ${ }^{16)}$ 。直達日射の強さが $120 \mathrm{~W} / \mathrm{m}^{2}$ 以上で あればたとえ雲が多く出ていても、晴天とみなした。

図 1 に示す感雨計は雨を指示させるためである。雨天の判別は、晴 天や曇天および日射に関係無く、感雨計によって降水があれば雨天と みなした。直達日射が $120 \mathrm{~W} / \mathrm{m}^{2}$ 未満で雨天でないときを曇天とみな した。このような晴天時・曇天時・雨天時の判別法には異論もあると 思われるが、本研究ではこのような基準に基づき判別をした。

\section{3 グローバル照度と全天空照度}

量天と雨天の場合は、グローバル照度計による測定值と遮蔽リング を備えた全天空照度計による測定值とを比べると両者は近似するが、 グローバル照度計による測定值の方が全体としてやや高い。本研究に おいてはグローバル照度計による測定值を全天空照度として取り扱っ た。曇天時または雨天時のグローバル照度は直射日光を含まないこと から全天空照度と同一のものとなるべき性質を持っているからである。 当然、晴天時の場合はグローバル照度計による測定值はグローバル照 度として取り扱った。

\section{4 野外昼光照度の平均值回帰式}

各季節における各天気の野外昼光照度 $(\mathrm{lx})$ の平均値の 3 次回帰式を 3.4.1〜 3.4.3 に掲げた。また、通年におけ斿天気の平均値回帰式 は3.4.4に記した。各式の $h$ は太陽高度 $(\mathrm{deg})$ である。平均值回帰は、 太陽高度 $1^{\circ}$ 毎の高度帯域を設け、その帯域に属する多くの測定値の うちから最大值を含む上方の $2.5 \%$ の個数の測定值と最小值を含む下 方の $2.5 \%$ 個数の測定値を除いた、いわば出現照度值の中央寄り 95\%レンジ内に属する照度值の平均値について行ったものである。

後述の如く、3.6において、3.4.1〜3.4.3 による昼光照度の平均値 回帰式から得られる值を、3.4.4 による通年の野外昼光照度の平均値 回帰式から得られる值と比較検討してみた。

\subsection{1 春秋季の測定結果の平均値回㷌式}

a) 晴天時グローバル照度

$$
\mathrm{E}_{\mathrm{fg}}=-0.58 h^{3}+51.88 h^{2}+361.3 h+2878.9
$$

b) 晴天時全天空照度

$$
\mathrm{E}_{\mathrm{fs}}=-9.39 \times 10^{-2} h^{3}+5.80 h^{2}+397.74 h+2686.2
$$

\section{c)罢天時全天空照度}

$\mathrm{E}_{\mathrm{cs}}=-0.2 h^{3}+16.27 h^{2}+296.17 h+1657.2$

d) 雨天時全天空照度

$\mathrm{E}_{\mathrm{rs}}=-6.44 \times 10^{-2} h^{3}+7.03 h^{2}+95.62 h+622.37$

\subsection{2 夏季の測定結果の平均値回帰式}

a) 晴天時グローバル照度

$\mathrm{E}_{\mathrm{fg}}=-0.38 h^{3}+37.59 h^{2}+448.27 h+3162.14$

b) 晴天時全天空照度

$$
\mathrm{E}_{\mathrm{fs}}=-6.62 \times 10^{-2} h^{3}+5.0 \not t^{2}+444.51 h+2970.47
$$

c) 最天時全天空照度

$\mathrm{E}_{\mathrm{cs}}=-0.11 h^{3}+10.95 h^{2}+349.52 h+1578.37$ 
d) 雨天時全天空照度

$\mathrm{E}_{\mathrm{rs}}=-4.81 \times 10^{-2} h^{3}+5.29 h^{2}+137.66 h+475.68$

\subsection{3 冬季の測定結果の平均値回帰式}

a)晴天時グローバル照度

$\mathrm{E}_{\mathrm{fg}}=-1.45 h^{3}+94.66 h^{2}+2.94 h+2978.54$

b) 晴天時全天空照度

$\mathrm{E}_{\mathrm{fs}}=-0.69 h^{3}+28.86 h^{2}+101.22 h+2838.25$

c) 曇天時全天空照度

$\mathrm{E}_{\mathrm{cs}}=-0.77 h^{3}+44.49 h^{2}-32.23 h+1903.39$

d) 雨天時全天空照度

$\mathrm{E}_{\mathrm{rs}}=-0.3 h^{3}+18.01 h^{2}+36.23 h+892.07$

\subsection{4 通年の測定結果の平均値回帰式}

a) 晴天時グローバル照度

$\mathrm{E}_{\mathrm{fg}}=-0.39 h^{3}+35.68 h^{2}+661.53 h+2945.70$

b) 晴天時全天空照度

$\mathrm{E}_{\mathrm{fs}}=-3.38 \times 10^{-2} h^{3}+3.20 h^{2}+406.72 h+2775.14$

c) 曇天時全天空照度

$\mathrm{E}_{\mathrm{cs}}=-9.31 \times 10^{-2} h^{3}+8.91 h^{2}+401.83 h+1687.62$ d) 雨天時全天空照度

$\mathrm{E}_{\mathrm{rs}}=-0.05 h^{3}+5.53 h^{2}+141.45 h+657.13$

\section{5 通年の昼光照度出現状況}

通年の晴天時、薷天時、雨天時の昼光照度デ一タの出現状況を図 2 に示す。図中の太害曲線は散布領域内の平均值回帰である。その各回

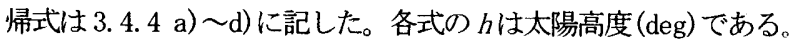

図中には 95 と記された破曲線が 2 本が描かれているが、これは $95 \%$ レンジの上限值と下限值の回帰曲線である。50 と記された 2 本の破曲 線は $50 \%$ レンジの上限值と下限值の回帰曲線である。

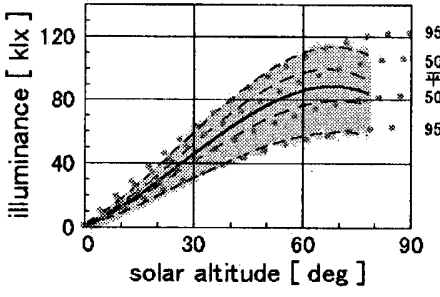

a) 晴天時グローバル照度

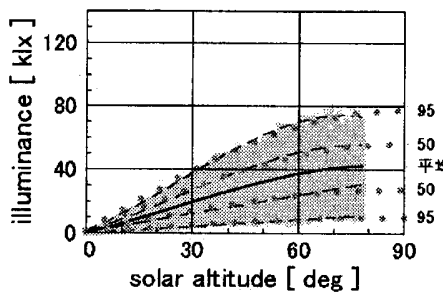

c) 量天時全天空照度

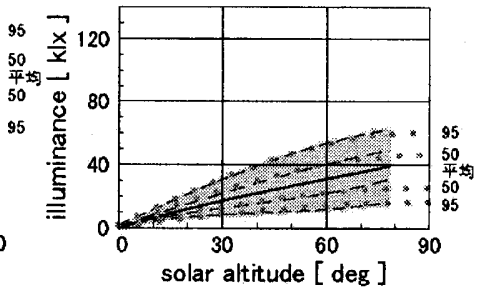

b) 晴天時全天空照度
図 2 通年の測定照度散布状況と平均值回帰曲線

\section{6 通年と各季節の照度比較}

太陽高度の変化に伴う昼光照度の変化が、通年と各季節とによって、 どの程度の差異が生じるかを検討する。

図 3 a), b), c), d) は太陽高度の変化に伴う昼光照度の平均値回帰曲 線の比較図である。図中の実曲線は通年の照度回帰曲線である。3 本 の異なる破曲線は表 1 に示寸各季節の照度回帰曲線である。

図 3 a)では、実曲線の通年によるものに対していずれの破曲線も近 似している。春秋季が最も実曲線に近似し、冬季の照度がわずかに高 く、夏季がわずかに低い傾向が見受けられる。
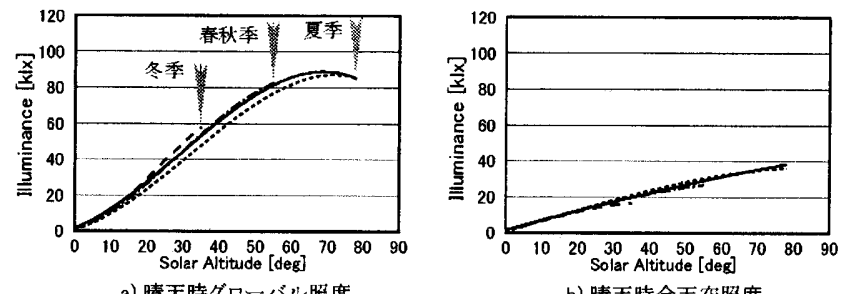

a) 晴天時グローバル照度

b) 晴天時全天空照度
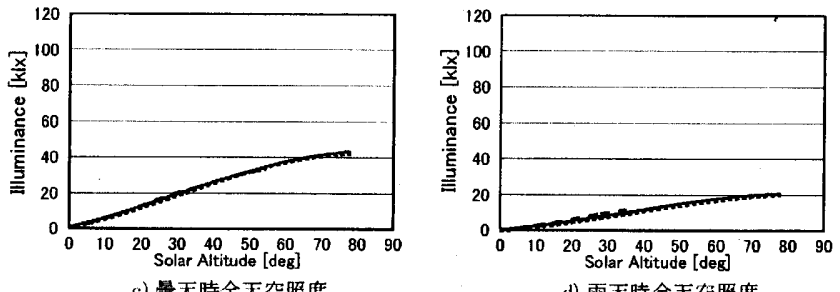

d) 雨天時全天空㬎度

図 3 通年と各季節との平均値回帰曲線の比較

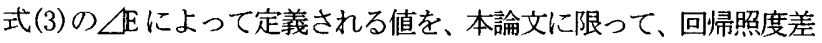
と呼ぶことにする。その值を各季節について図示したものが図 4.1 a), b), c), d)、図 4.2 a), b), c), d)、図 4.3 a), b), c), d) である。

回㷌照度差 $\triangle \mathrm{E}=$ (各季節の高度毎の平均照度の回帰値 $)$ - (通年の高度毎の平均照度 $の$ 回帰值) $\cdots(3)$

晴天時グローバル照度の $\Delta \mathrm{E}$ は変動が各季とも大きく(図 4.1 a), 図 $4.2 \mathrm{a})$, 図 $4.3 \mathrm{a})$ )、この内でも、夏季の $\triangle \mathrm{E}$ (図 $4.2 \mathrm{a}$ )) は負で絶対値 が最大であった。また、表 2 は各季節の昼光照度の回帰照度差 $\Delta \mathbb{E} の$ 最大值を絶対値で示したものである。

| 代 | は最大でも約 4500～5000 1x の範囲に読み取ることができ、 通年の高度毎の平均照度の回帰值に対する割合は 7 〜 $11 \%$ 範囲であ る。

| $\triangle \mathrm{E} \mid$ の季節的な傾向は明確な一貫した徴候としては捉え難いも のであった。

表 2 回帰照度差の最大值(絶対值で示す)

\begin{tabular}{|l|l|l|l|}
\hline & 春秋季[1x] & 夏季[1x] & 冬季[1x] \\
\hline \hline 晴天時グローバル照度 & 1838 & 4886 & 4430 \\
\hline 晴天時全天空照度 & 2727 & 3841 & 2583 \\
\hline 曇天時全天空照度 & 2114 & 1324 & 549 \\
\hline 雨天時全天空照度 & 451 & 1722 & 474 \\
\hline
\end{tabular}




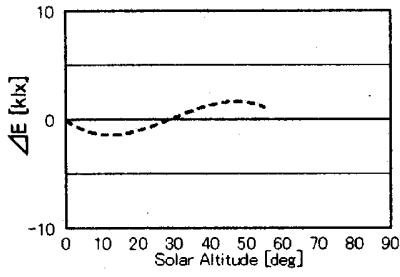

a) 晴天時グローバル照度

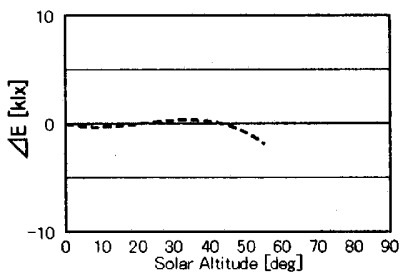

c) 天時全天空照度

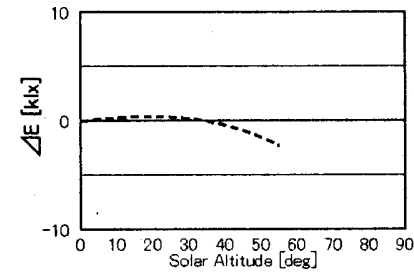

b）晴天時全天空照度

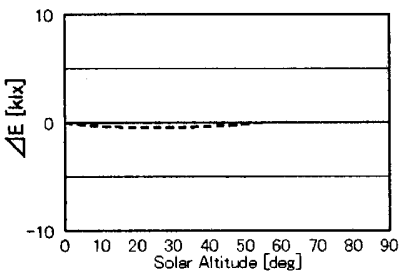

d) 雨天時全天空照度

図 4.1 春秋季の回帰照度差

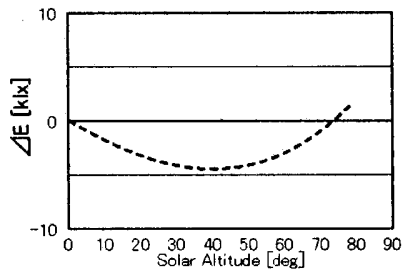

a) 暗天時グローバル照度

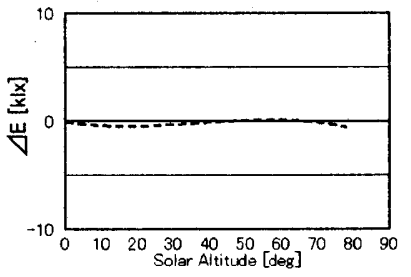

c) 天時全天空照度

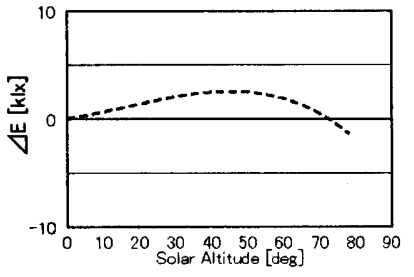

b）晴天時全天空照度

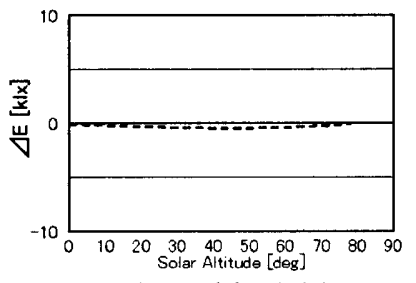

d) 雨天時全天空照度

図 4.2 夏季の回帰照度差

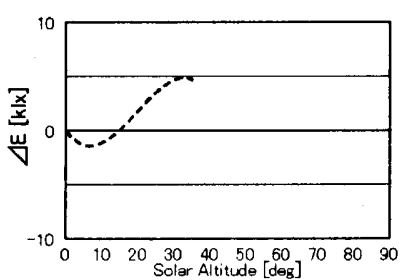

a) 晴天時グローバル照度

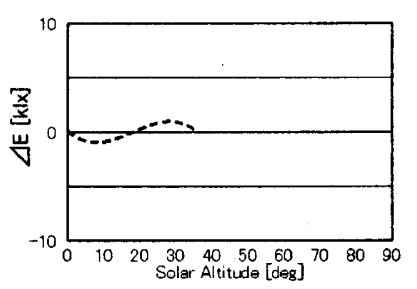

c) 量天時全天空照度

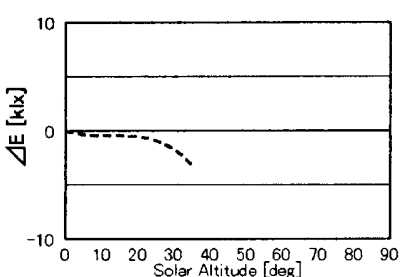

b) 晴天時全天空照度

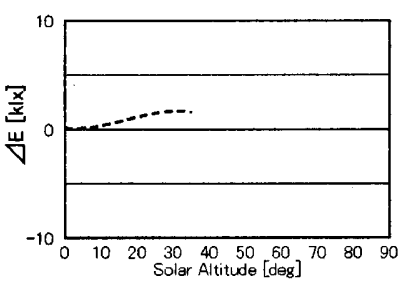

d) 雨天時全天空照度

図 4.3 冬季の回帰照度差

図 3 による以上の検討から、昼光照度は太陽高度が同一であるなら ば、季節によって大きく変わることはないことが見受けられる。

このことから、季節によって出現する太陽高度は異なるが、季節そ のものは昼光照度の主要な変動要因と考えなくてもよいと思われる。 とは言え、太陽高度が高いのは夏季だけの現象であるから、太陽高度 が高いときの昼光照度には変動要因としての夏季の特徵が反映してい るとも言うべきかも知れない。

\section{4. 平均的代表的な野外昼光照度の予測近似算定式の導出}

通年における野外昼光照度の平均値の回帰式を 3.4 .4 で示したが、 ここでは、これら 4 つ式を 1 つ式にまとめることを試みる。その 目的に叶う式の形としては次の式(4)のようなものが考えられる。式 (4)は単純な形をしているが、その式から導かれる值が実用上、十分満 足できる精度を有するならば、それが実用的であると考えて、この形 を選んだ。言うまでもないが、この式の $E_{a p p}$ は晴天時のグローバル照 度または晴天時・曇天時・雨天時の全天空照度の何れかの予測近似值 を表す。

$$
E_{a p p}=A \cdot \sin h+B
$$

式(4)の A および B を適切に定めてやれば、前節の 3.4 .4 の各式が 網羅される。

式(4)のAは、式の形からして、太陽高度が十分高い時(すなわち、 $\sin h$ が 1 に近い時) の推定すべき昼光照度を意味することになるから、 ここではAとして名古屋における太陽高度が十分に高い時の昼光照度 を採用することが考えられる。太陽高度が十分高い時の昼光照度は天 気によって異なるから、天気によって異なった值を採用しなければな らない。

B は、太陽高度 $h=0^{\circ}$ の時の昼光照度を意味し、これも、天気によ って異なった值となる。

\section{1 A 項についての考察}

\subsection{1 天気依存俰数 $\omega$}

野外昼光照度は太陽高度 $h$ の上异に伴い増加寸るが、天気の違い晴 天時、量天時、雨天時)によっても大きく変わる。

そこで、太陽高度の等しい時の晴天時グローバル照度に対する各天 気における全天空照度、並びに晴天時グローバル照度自身の比(式 (4.1.1) (4.1.4)) を天気依存保数 $\omega$ と定義し、以下の検討において 活用することにした。 $\omega$ には $\omega_{f}, \omega_{c}, \omega_{r}, \omega_{f g}$ の 4 種がある。

$$
\begin{array}{ll}
\omega_{f}=E_{f} / E_{f g} & \cdots(4.1 .1) \\
\omega_{c}=E_{c} / E_{f g} & \cdots(4.1 .2) \\
\omega_{r}=E_{r} / E_{f g} & \cdots(4.1 .3) \\
\omega_{f g}=E_{f g} / E_{f g}=1 & \cdots(4.1 .4)
\end{array}
$$

ただし、このあと 4.1.2で述べるように、

$E_{f} \quad$ : 晴天時における太陽高度 $h$ の時の全天空照度

$E_{c} \quad$ : 曇天時における太陽高度 $h$ の時の全天空照度

$E_{r} \quad$ : 雨天時における太陽高度 $h$ の時の全天空照度

$E_{f g} \quad:$ 太陽高度 $h$ の時の晴天時グローバル照度

$\omega_{f}, \omega_{c}, \omega_{r}, \omega_{f g}$ は式(4)の A 項の一部あり、 $E_{a p p}$ の説明変数と して位置付けられる。図 5 は太陽高度の変化に伴う天気依存係数 $\omega$ の 
変化を表す。図より、 $\omega_{f}, \omega_{c}, \omega_{r}, \omega_{f g}$ は太陽高度 $5^{\circ}$ 以下の時を除 くと、それぞれがほぼ一定の值となっていることがわかる。このこと から、太陽高度が十分に高いときの $\omega$ の值として、太陽高度 $35^{\circ}$ の時 の值を採用することにした。表 4 にその值を示す。

$\mathrm{h}\left\langle 5^{\circ}\right.$ のとき、 $\omega_{f}=0.37$ を用いて $E_{f}$ を求めると、 $E_{f}$ の誤差は 大きくなるが、 $E_{a p p}$ 算定にはこれに $\sin h($ その值はかなり小さい) を掛けたものを用いるから、 $E_{a p p}$ に対するその影響は小さい。

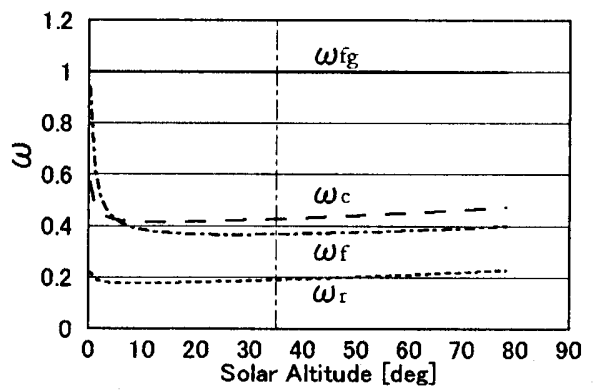

図 5 天気依存係数の太陽高度に対する関係

\subsubsection{A 項の組み立て}

既に述べたように、式(4)のA としては、太陽高度が十分に高い時の 昼光照度を採用寸ればよい。名古屋地方における晴天時のグローバル 照度の予測式のための $\mathrm{A}$ としては、名古屋地方で晴天時に太陽高度が 十分高い時に出現するグローバル照度の平均的な値 $E_{f g} \cdot h a \cdot$ mean を 採用すればよい。晴天時・纍天時・雨天時の全天空照度の予測式の A としては、 $E_{f g} \cdot n a \cdot$ mean にそれぞれ天気依存係数 $\omega_{f} ， \omega_{c} ， \omega_{r}$ を掛 けたものを用いればよい。すなわち、Aは次式のように表される。

$$
A=\omega \cdot E_{f g \cdot h a \cdot \text { mean }} \quad \cdots(4.1 .5)
$$

次に、 $E_{f g} \cdot h a \cdot$ mean として、どのような值を採用すべきかを、実測で 得られたデータに照らして、試行錯誤的に検討した結果、その値とし て、93000(1x)を採用することがほぼ妥当であることがわかった。

$E_{f g} \cdot h a \cdot$ mean の值を $93000 \mathrm{~lx}$ と決定する過程では、式(4)の形を 考慮して、「3.5 通年の昼光照度出現状況」で述べた晴天時グローバル 照度の $95 \%$ レンジの平均値のうちで太陽高度 $h$ が高い時の值を $\sin h$ で割った值をいくつか $E_{f g} \cdot h a \cdot$ mean の候補として検討した。その結果、 最終的に $930001 \mathrm{x}$ の值にたどりついた。

添え字の haにはhigh altitude の意味を持たせたつもりである。

\subsection{B 項についての考察}

式(4)の中の B は、 $h=0^{\circ}$ の時の昼光照度を意味する。ここでは、 これを初期照度と呼ぶことにする。

上述の A 項と同様に、B を、晴天時グローバル初期照度 $E_{j g, h=0}$ に 初期天気依存係数 $\omega^{\prime}$ を掛けて表すことにする。すなわち、

$$
B=\omega^{\prime} \cdot E_{f g, h=0}
$$

とする。式(4.2)の $\omega^{\prime}$ には 4.2.2 で述べる $\omega_{f g}^{\prime}, \omega_{f}^{\prime}, \omega_{c}^{\prime}, \omega_{r}^{\prime}$ の何 れかを用いる。

\subsection{1 初期照度}

晴天時グローバル初期照度 $E_{f y, h=0}$ は、太陽高度 $h か ゙-2^{\circ}<h<2^{\circ}$ の時の晴天時グローバル照度のデータを整理検討した結果、その值と して、1500 1x を採用することにした。表 3 と表 4 にはその值を示す。
表 3 各天気に対する初期照度

\begin{tabular}{l|lll}
\hline 天気 & 昼光光源 & 初期照度 $[1 \mathrm{x}]$ \\
\hline \multirow{2}{*}{ 晴天時 } & グローバル照度 $\left(\mathrm{E}_{\mathrm{fg}}\right)$ & 1500 \\
& 全天空照度 & $\left(\mathrm{E}_{\mathrm{fs}}\right)$ & 1400 \\
\hline 墨天時 & 全天空照度 & $\left(\mathrm{E}_{\mathrm{cs}}\right)$ & 800 \\
\hline 雨天時 & 全天空照度 & $\left(\mathrm{E}_{\mathrm{rs}}\right)$ & 300 \\
\hline
\end{tabular}

\subsection{2 初期天気依存俰数 $\omega^{\prime}$}

初期天気依存係数 $\omega^{\prime}$ を、晴天時グローバル初期照度 $E_{f 8, h=0}$ に対 する晴天時・曇天時・雨天時の全天空初期照度並びに晴天時グローバ ル初期照度自身の比によって式(4.2.4)〜(4.2.7)のように定義する。 測定データを検討した結果、 $\omega^{\prime}$ の值として、表 4 に示すような值を得 た。この $\omega^{\prime}$ を用いれば当然、種々の天気における初期照度を求めるこ とができる。

$$
\begin{array}{ll}
\omega_{f}^{\prime}=E_{f, h=0} / E_{f g, h=0} & \cdots(4.2 .4) \\
\omega_{c}^{\prime}=E_{c, h=0} / E_{f g . h=0} & \cdots(4.2 .5) \\
\omega_{r}^{\prime}=E_{r, h=0} / E_{f g h h=0} & \cdots(4.2 .6) \\
\omega_{f g}^{\prime}=E_{f g, h=0} / E_{f g, h=0}=1 & \cdots(4.2 .7)
\end{array}
$$

ただし、

\begin{tabular}{|c|c|c|c|c|}
\hline & $\begin{array}{c}\text { 晴天時 } \\
\text { タロローバル照度 }\end{array}$ & $\begin{array}{c}\text { 晴天時 } \\
\text { 全天空照度 }\end{array}$ & $\begin{array}{c}\text { 曇天時 } \\
\text { 全天㔖琞度 }\end{array}$ & $\begin{array}{l}\text { 雨天時 } \\
\text { 全天空燳度 }\end{array}$ \\
\hline$\omega$ & 1 & 0.37 & 0.43 & 0.21 \\
\hline$\omega^{\prime}$ & 1 & 0.94 & 0.57 & 0.22 \\
\hline
\end{tabular}

$E_{f, h=0} \quad$ : 晴天時の全天空初期照度

$E_{c, h=0} \quad$ : 曇天時の全天空初期照度

$E_{r, h=0}:$ 雨天時の全天空初期照度

$E_{f g, h=0} \quad$ : 晴天時のグローバル初期照度

表 4 式(5)で用いる值

\section{5. 導出された予測近似算定式}

以上の検討を経て導出された平均的な野外昼光照度の予測近似算定 式は式(5)のように表される。

$$
E_{a p p}=E_{f g, h=0} \cdot \omega^{\prime}+E_{f g \text {.ha.mean }} \cdot \sin h \cdot \omega \quad \cdots(5)
$$

ただし、

$$
\begin{array}{ll}
E_{f g . h a, \text { mean }} & \text { : 晴天時の十分に太陽高度が高い時の } \\
& \text { グローバル照度 }(93000 \mathrm{~lx}) \\
E_{f g, h=0} & : \text { 晴天時のグローバル初期照度 }\left(\begin{array}{ll}
1500 & 1 \mathrm{x}
\end{array}\right) \\
\omega & : \text { 天気依存保数 (表 } 4 \text { 参照) } \\
\omega^{\prime} & : \text { 初期天気依存係数 (表 } 4 \text { 参照) }
\end{array}
$$

晴天時の平均的代表的なグローバル照度や晴天時・最天時・雨天時 の平均的代表的全天空照度の予測近似算定式として、表 4 および式(5) を参照して、式(5.1)〜 (5.4)が導かれる。 
さて、式(5)から得られる照度の值は、昼光照度のいわば平均的で代 表的な值である。現実に出現している昼光照度の值が式(5)から得られ る值よりも大きい場合や小さい場合が数多くあることは、図2に示す 4 つのグラフからも明らかである。このことから、本論文で取り扱っ ている 4 種の昼光照度に関して、その出現頻度の $95 \%$ レンジの上限 值・下限値や $50 \%$ レンジの上限值・下限值を予測可能にする近似式は 有用と思われるので、ここで、その近似式の導出を試みた。

図 2 のつのグラフに示されている実測值の散布状況を検討してみ たところ、上述のいくつかのレンジの上限值・下限值の予測式は、既 に遒出してある平均野外昼光照度予測のための式(5) に適当な保数を 挂けたものが十分に実用的であると思われた。そこで、図2 並びにそ の基になった多くの照度測定值に考察を加えた結果、表 5 に示寸係数 を得た。

これらの倸数を用いて、既に求めた予測近似算定式に加えて、95\% レンジおよび50\%レンジの上限と下限(図 2 a), b), c),d) の破曲線)の 概数值を求める算定式を求めてみたので、それらを以下に示す。

式(5.1)〜 (5.4)の各々の下には 95\%レンジおよび 50\%レンジの上 限值・下限值の計算式を示した。これらの式でも 3.4 と同様の記号 $\mathrm{Efg} \cdot \mathrm{Efs} \cdot \mathrm{Ecs} \cdot \mathrm{Ers}$,を用いているが、ここでは、それらは、それぞれ 晴天時のグローバル照度並びに晴天時・昙天時・雨天時の全天空照度 の平均的代表的な值を表すものとする。なお、式(5.1.1)〜 (5.4.4)の 分布状況は図 2 a),b),c)，d)に薄太丸点でプロットした。

表 5 レンジ上下限値を決める係数

\begin{tabular}{|c|c|c|c|c|c|}
\hline \multicolumn{2}{|c|}{} & $\begin{array}{c}\text { 晴天時 } \\
\text { グローバ }\end{array}$ & $\begin{array}{c}\text { 睛天時 } \\
\text { 全天空 }\end{array}$ & $\begin{array}{c}\text { 量天時 } \\
\text { 全天空 }\end{array}$ & $\begin{array}{c}\text { 雨天時 } \\
\text { 全天空 }\end{array}$ \\
\hline \multirow{2}{*}{$\begin{array}{c}95 \% \\
\text { レンジ }\end{array}$} & 上限值 & 1.3 & 1.7 & 1.9 & 2.5 \\
\cline { 2 - 6 } & 下限值 & 0.67 & 0.47 & 0.25 & 0.20 \\
\hline \multirow{2}{*}{$\begin{array}{c}50 \% \\
\text { レンジ }\end{array}$} & 上限值 & 1.12 & 1.3 & 1.38 & 1.58 \\
\cline { 2 - 6 } & 下限值 & 0.88 & 0.72 & 0.68 & 0.75 \\
\hline
\end{tabular}

記号：95\%レンジの上限值・下限值; $\mathrm{E}_{\mathrm{fg}} \cdot \mathrm{ll}, \mathrm{E}_{\mathrm{fg} \cdot \mathrm{L}}$ 等。

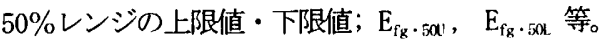

晴天時グローバル照度

$$
\begin{array}{rlr}
E_{f g} & =1500 \times 1+93000(\sin h) \times 1 & \cdots(5.1) \\
\mathrm{E}_{\mathrm{fg} \cdot 1}=E_{f g} \times 1.3 & \cdots(5.1 .1) \\
\mathrm{E}_{\mathrm{fg} \cdot \mathrm{L}}=E_{f g} \times 0.67 & \cdots(5.1 .2) \\
\mathrm{E}_{\mathrm{fg} \cdot 5 \mathrm{al}}=E_{f g} \times 1.12 & \cdots(5.1 .3) \\
\mathrm{E}_{\mathrm{fg} \cdot 5 \mathrm{~L}}=E_{f g} \times 0.88 & \cdots(5.1 .4)
\end{array}
$$

\section{晴天時全天空照度}

$$
\begin{array}{ll}
E_{f s}=1500 \times 0.94+93000(\sin h) \times 0.37 & \cdots(5.2) \\
\mathrm{E}_{\mathrm{fs} \cdot 1 \mathrm{l}}=E_{f s} \times 1.7 & \cdots(5.2 .1) \\
\mathrm{E}_{\mathrm{fs} \cdot \mathrm{L}}=E_{f s} \times 0.47 & \cdots(5.2 .2) \\
\mathrm{E}_{\mathrm{fs} \cdot 50 \mathrm{l}}=E_{f s} \times 1.3 & \cdots(5.2 .3) \\
\mathrm{E}_{\mathrm{fs} \cdot 5 \mathrm{~L}}=E_{f s} \times 0.72 & \cdots(5.2 .4)
\end{array}
$$

曇天時全天空照度

$$
\begin{array}{ll}
E_{c s}=1500 \times 0.57+93000(\sin h) \times 0.43 & \cdots(5.3) \\
\mathrm{E}_{c s \cdot 1}=E_{c s} \times 1.9 & \cdots(5.3 .1) \\
\mathrm{E}_{c s \cdot \mathrm{L}}=E_{c s} \times 0.25 & \cdots(5.3 .2) \\
\mathrm{E}_{c s \cdot 5 a}=E_{c s} \times 1.38 & \cdots(5.3 .3) \\
\mathrm{E}_{c s .50 .}=E_{c s} \times 0.68 & \cdots(5.3 .4)
\end{array}
$$

雨天時全天空照度

$$
\begin{array}{ll}
E_{r s}=1500 \times 0.22+93000(\sin h) \times 0.21 & \cdots(5.4) \\
\mathrm{E}_{\mathrm{rs} \cdot \mathrm{U}}=E_{r s} \times 2.5 & \cdots(5.4 .1) \\
\mathrm{E}_{\mathrm{rs} \cdot \mathrm{L}}=E_{r s} \times 0.20 & \cdots(5.4 .2) \\
\mathrm{E}_{\mathrm{rs} \cdot 5 \mathrm{Q}}=E_{r s} \times 1.58 & \cdots(5.4 .3) \\
\mathrm{E}_{\mathrm{rs} \cdot 5 \mathrm{l}}=E_{r s} \times 0.75 & \cdots(5.4 .4)
\end{array}
$$

\section{6. 予測近似曲線と平均值回㷌曲線の比較}

既述の平均值回帰曲線に対して予測近似算定式(5.1)〜 (5.4)がどの 程度の精度を持つかを比較検討する。そのために、図 6 a),b),c),d) では破曲線で 3.4 .4 の諸式のグラフを描き、実曲線で式(5)のグラフを 描いて、相互の比較を行った。

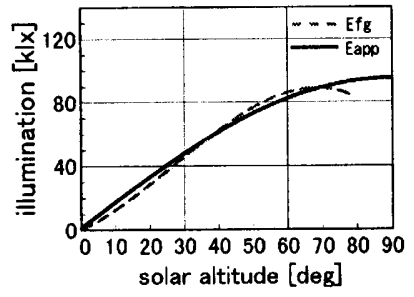

a）晴天時グローバル照度

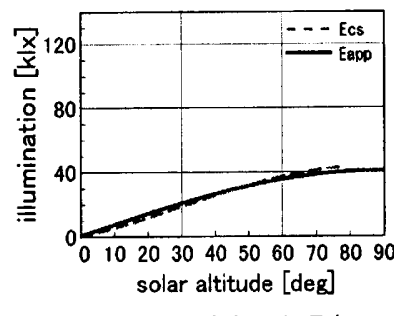

c) 最天時全天空照度

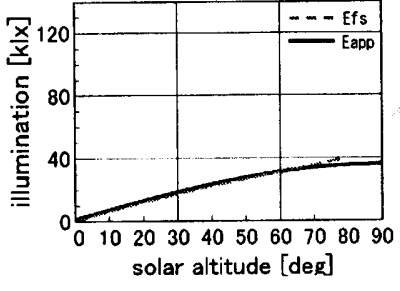

b) 晴天時全天空照度

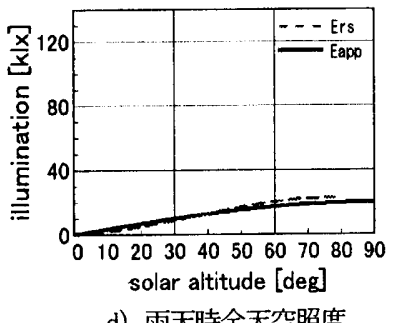

d) 雨天時全天空照度
図 6 予測近似曲線と年間の平均值回帰曲線

図6 a)の中の破曲線や図 2 a),d)の中のいくつかの曲線において、 太陽高度が非常に高い部分で照度の违减傾向が見受けられる。しかし これは、晴天時グローバルや雨天時全天空照度が本来持っている性質

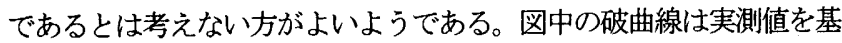
に描かれたものではあるが、図中のこれらの曲線には測定期閒中の特 異性が反映していると思われる。太陽高度が非常に高くなっている時 間の年間合計は、昼間の時間の年間合計に比べると非常に短い。従つ て、太陽高度が非常に高い時の測定データの個数が少ないために、測 定期間中に生じたわずかの異常データが集計結果にそのまま反映して しまうと考えられるからである。

これらのことを考慮にいれて図6をながめると、それぞれの図中の 2 本の曲線は互いによく近似しており、図中の破曲線は、もともと実 
状をよく表現する回帰式のグラフであるから、名古屋地方において実 用に耐える昼光照度の予測值を、式(5) と表 4 または 5.に揭げる諸式 から求めることが出来るものとして良いと思われる。

\section{7. 結 語}

名古屋において障害物の無い建物屋上で野外昼光照度の測定を行い、 その測定データを晴天時・显天時・雨天時に分類した。天気分類した 昼光照度データを更に冬季・春秋季・夏季の 3 種に整理して、通年の データとの比較検討を行った。その結果、季節的な顕著な傾向は見受 けられなかった。

名古屋地方に関する限り、1）野外昼光照度は、太陽高度が同一であ るならば、季節の相違によっては変わらない、2）昼光照度の主たる変 動要因は太陽高度と天気である、との知見を得た。

平均的な野外昼光照度の予測近似値 $E_{a p p}$ の算定式として式(5)を 提示し、式(5)の計算に必要な $2 \supset$ の定数 $E_{f g} \cdot h a \cdot$ mean,$E_{f g h n-0}$ の值 とそれぞれ 4 つずつの $\omega, \omega^{\prime}$ の値を表 4 に示した。併せて、95\%レ ンジ・50\%レンジ の上限值・下限值の算定式を 5 .に提示した。筆者 らは、これらの式は十分に実用上に耐えるものと考えている。

謝辞 : 最後になりましたが、この論文の作成にあたり、永田忠彦・福井大 学名誉教授には多大なるご助言をいただきましたことに対して、深く感謝 の意を表します。

\section{参考献}

1）～6）小木會定彰：昼光光源に関する研究 (1)～(VI), 照明学会雑誌, Vol. 26-5 (1942. 5), Vol. 27-3(1943. 3), Vol. 27-7 (1943. 7), Vol. 29-5 (1945. 5), Vol. 31-5 (1947.5), Vol.37-5(1953.5)

7）永田忠彦,澤田康二:晴天空による水平面散乱日射の式の試案, 日本建築学会 学術講演梗概集, pp. 519-520, 1978.9

8）氷田忠彦,澤田康二：天空日射に関する Berlage の式に対する疑問, 日本建 築学会学術講演梗概集, pp. 381-382, 1975.10

9）井川憲男ほか：標準天空としての all sky model の提案, 第 1 報, 天空輝度分 布の测定, テー夕の整備, 天空輝度分布の指摆, 照明学会誌論文, Vol. 85, №2, pp. $131-140,2001$

10）井川憲男ほか : 標準天空としての all sky model の提案, 第 2 報, すべての 天空状態の天空輝度分布を表す数式, 照明学会誌論文号, Vol. 85, №5, pp. 323331,2001

11）村山晴奈, 宗政幹夫, 西安男 : グローバル照度と全天空照度について（夏季 . 天笖採光における室内予測照度として)その 1 , 日本建築学会 2000 年度大会 (東 北) 学術講演梗概集, D-1, 腊境工学 I, pp. 475-476, 2000.9

12）伊藤孝一,安達寛益, 村山晴奈, 宗政幹夫, 西安男 : 春秋季 ·天空採光におけ る室内照度予測のためのグローバル照度と全天空照度の測定 その1, 日本建築 学会東海支部研究報告集, 第 39 号, pp. 341-344, 2001.2

13）宗政幹夫, 村山睛奈, 西安男 : 冬季・側空採光における室内照度予測のため の $1 / 2$ グローバル照度と $1 / 2$ 全天空照度 その 4 , 日本建築学会東海支部研究報 告集,第 39 号, pp. 353-356, 2001.2

14）安達寛益,伊藤孝一, 西安男: 野外昼光の年間評価-天空および㑡空の予湘近 似算定式について(その1), 日本建築学会東海支部研究報告集, 第 41 号, pp. 441$444,2003.2$
15）大竹克佳, 米山康道, 标原佳伸, 西安男: 天空採光による室内照度予測のため の野外昼光照度と計算図(世界各地)その 1 , 日本建築学会大会学術講演梗概集 (東海), pp. 353-354, 2003.9

16）気象庁：地上気象観測指針, $p 75,2002.3$ 